\title{
Status of mineral nitrogen fertilization and net mitigation potential of the state fertilization recommendation in Chinese cropland
}

\author{
Guo Zhang, Xiaoke Wang, Binfeng Sun, Hong Zhao, Fei Lu* , Lu Zhang \\ State Key Laboratory of Urban and Regional Ecology, Research Center for Eco-Environmental Sciences, Chinese Academy of Sciences, Beijing 100085, PR China
}

\section{A R T I C L E I N F O}

\section{Article history:}

Received 19 November 2014

Received in revised form 18 March 2016

Accepted 27 March 2016

Available online 9 April 2016

\section{Keywords:}

Carbon sequestration

Greenhouse gas

Net mitigation potential

Nitrogen fertilizer

Optimum fertilization

\begin{abstract}
A B S T R A C T
The overuse of mineral nitrogen ( $\mathrm{N}$ ) fertilizer is widespread and affects greenhouse gas (GHG) emission in China. In 2013, the Ministry of Agriculture released the 'Recommendation for soil nutrient analysis-based mineral fertilizer application for corn, wheat and rice' (hereafter the Recommendation). The aims of this study were to estimate current mineral $\mathrm{N}$ fertilization and net mitigation potential (NMP) for the Recommendation in the three main crops in China. To estimate the NMP from the Recommendation concerning the fertilizer recommendation (FR) scenario, we designed a current situation (CS) scenario by conducting a field questionnaire survey across typical cropping regions in China. Our results indicate that annual $\mathrm{N}$ fertilization amount was $19.1 \pm 1.2$ (95\% confidence interval) Mt N applied to the $66 \mathrm{M}$ ha of Chinese cropland in the CS scenario and would decrease by about 7.1 $\mathrm{Mt} \mathrm{N}$ in the FR scenario. This decrease might mitigate $37.4 \pm 5.2 \%$ of GHG emissions including carbon dioxide $\left(\mathrm{CO}_{2}\right)$ from production and transport of $\mathrm{N}$ fertilizer, and nitrous oxide from soil due to $\mathrm{N}$ fertilization. Car-

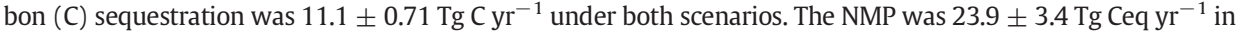
the FR scenario and might offset $1.1 \pm 0.16 \%$ of $\mathrm{CO}_{2}$ emissions from fossil fuel combustion in 2011 in China. In conclusion, implementation of the Recommendation could be a sustainable and cost-effective $\mathrm{N}$ management system to mitigate GHG emissions in Chinese cropland.
\end{abstract}

(c) 2016 Elsevier Ltd. All rights reserved.

\section{Introduction}

Mineral nitrogen $(\mathrm{N})$ fertilization contributes to global climate change by affecting greenhouse gas (GHG) emissions and mitigation (Lu et al., 2009; Schlesinger, 2009). The production and transport of $\mathrm{N}$ fertilizer emit carbon dioxide $\left(\mathrm{CO}_{2}\right)$ from the fossil fuel used (Lal, 2004; West and Marland, 2002). Moreover, the $\mathrm{N}$ fertilizer application to cropland results in more nitrous oxide $\left(\mathrm{N}_{2} \mathrm{O}\right)$ emission from soil (Lal, 2007). However, $\mathrm{N}$ fertilization can also improve soil carbon sequestration (SCS) by increasing crop yield and residue input (Du et al., 2014). Therefore, altering $\mathrm{N}$ fertilization affects $\mathrm{GHG}$ emissions and mitigation in cropland.

Suitable N fertilization is difficult to predict, and hence excessive $\mathrm{N}$ fertilization is popular in Chinese croplands (Ju et al., 2009). This overuse of $\mathrm{N}$ fertilization reduces $\mathrm{N}$ use efficiency (Ma et al., 2008) and increases GHG emissions (Schlesinger, 2009). Some management systems have been developed to improve $\mathrm{N}$ fertilization practices (Jia et al., 2013; Ju et al., 2009; Peng et al., 2010). For example, site-specific $\mathrm{N}$ management reduces $\mathrm{N}$ fertilizer application by $32 \%$ compared with farmers' N management in rice (Peng et al., 2010). The 'Soil Testing and Formulated Fertilization system' was conducted at a national

\footnotetext{
* Corresponding author at: 18 Shuangqing Road, Haidian District, Beijing 100085, PR China.

E-mail addresses: guozhang@rcees.ac.cn (G. Zhang), feilu@rcees.ac.cn (F. Lu).
}

scale, starting from 2005 and extended to $42.7 \mathrm{M}$ ha of Chinese croplands in 2007 (Gao, 2008). Based on these studies, a fertilization system was released entitled 'Recommendation for soil nutrient analysis-based mineral fertilizer application for corn, wheat and rice' (hereafter the Recommendation) by the Ministry of Agriculture of the People's Republic of China (MOA, 2013). The Recommendation provides producing regions and crop yields specific criteria for suitable fertilizer management for each crop. Considering the regional heterogeneity of climate and cropping practices, the croplands were divided into four, five and five producing regions for corn, wheat and rice production, respectively (MOA, 2013). Therefore, the $\mathrm{N}$ fertilization suggestion in one province is available according to producing region and yield for each crop.

Any change in $\mathrm{N}$ fertilization has the potential to alter GHG emissions. However, the current status of $\mathrm{N}$ fertilization is little known in corn, wheat and rice throughout China. Furthermore, clarification is required concerning how implementation of the Recommendation would affect GHG emissions in cropland. Our hypothesis was that the implementation would decrease $\mathrm{N}$ fertilization and mitigate the resulting GHG emissions. Therefore, the objectives of this study were to estimate (1) the current mineral $\mathrm{N}$ fertilization and (2) net mitigation potential (NMP) of the Recommendation in these three crops in China. Thus, we conducted a field questionnaire survey across typical cropping regions in China during 2012-2013 and estimated the NMP of the Recommendation by designing two scenarios based on the survey and the Recommendation. 


\section{Materials and methods}

\subsection{Study region}

This study was conducted in mainland China, where rice, wheat and corn are the main cereal crops. In 2011, these crops occupied 54\% of the total sown cropland area and $89 \%$ of the total cereal yield (NBS, 2012). Chinese cropland is divided into four cropping regions according to heterogeneity of climate, cropping systems and cultivation (Lu et al., 2009): Northeast, North, Northwest and South China (Fig. 1). The cropping system is mainly single crops of corn, rice or wheat in one year in Northeast and Northwest China. The rotation is mainly corn-wheat in North China and mainly wheat-rice or even wheat-rice-rice in South China (Lu et al., 2009). However, other cropping systems may be adopted in some provinces due to climate and small-scale farmers' choices, for example both single and double cropping systems in Shaanxi in Northwest China.

\subsection{Field survey}

During 2012-2013, we conducted a survey with a field questionnaire for farmers concerning cropland management in main crops across 2011 throughout mainland China (Fig. 1). The survey questions included crop yields and mineral $\mathrm{N}$ fertilizations (Table A1 in Appendix). Meanwhile, the triangulation questions, including crop yield and fertilizer price, were designed to ensure questionnaires' validity (Table A1 in Appendix). The survey comprised four processes: (1) pilot survey: since there is huge spatial heterogeneity in fertilization due to climate, soil and cropping system in China, sampling size was a big challenge in the present study. We conducted a pilot survey in the counties of Yanzhou, Tengzhou and Tongcheng which are located in major production regions of wheat, corn and rice (Text A1 in Appendix). The pilot survey showed that $\mathrm{N}$ fertilization rate was $251 \pm 51 \mathrm{~kg} \mathrm{~N} \mathrm{ha}^{-1} \mathrm{yr}^{-1}$ (mean \pm standard deviation, $\mathrm{n}=52$ ). The sample size ( $\mathrm{n}$ ) of formal survey was estimated with Formula (1) (Townend, 2002):

$\mathrm{n}=\left(\mathrm{SD} * t_{\mathrm{n}-1,0.05} / 95 \% \mathrm{CI}\right)^{2}$

where SD is standard deviation of the $\mathrm{N}$ fertilization rate of the pilot survey, $t_{\mathrm{n}-1,0.05}=1.96$ obtained from $t$-tables and $\mathrm{CI}$ is confidence interval. Therefore, the sample size of 410 was suitable using an acceptable $95 \% \mathrm{CI}=5$. To control the risk of uncertain factors, we adopted 850 as the sample size in the formal survey; (2) interviewer training: interviewers were solicited from China Agricultural University and trained concerning interview principles and respondent selection. They were also given detailed explanations of survey questions in a uniform questionnaire. The interviewer of the pilot survey served as not only the interviewer in the formal survey, but also the guiders in the training of the members solicited; (3) formal survey: in each province, two to five counties were randomly selected according to cropland area, with at least one village per county. In each village, five farmers were selected with a simple random sampling method during field-labor time by the interviewers. The interviewers spoke with the farmers selected and filled in the improved questionnaires based on the pilot survey. The

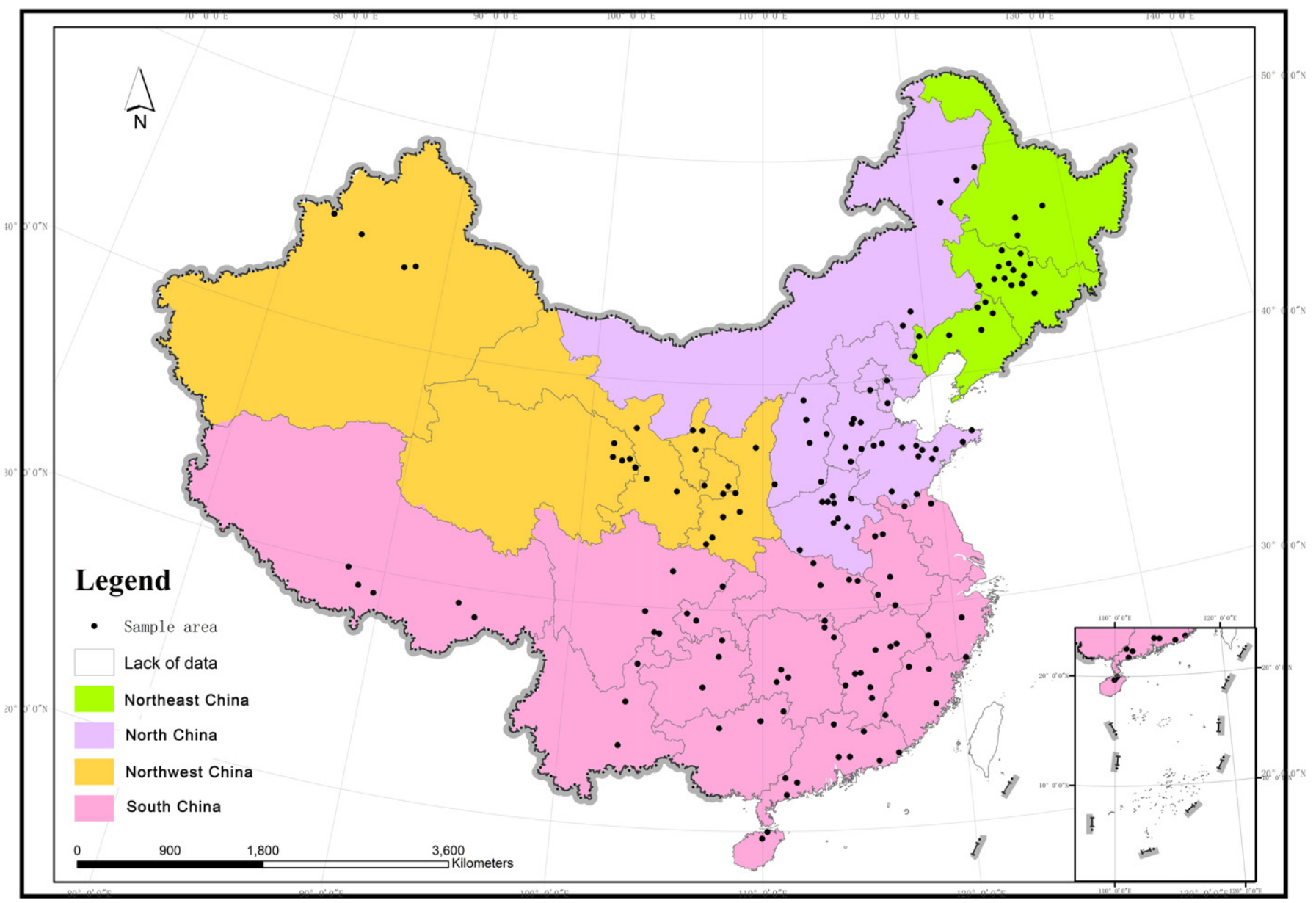

Fig. 1. The distribution of counties investigated in China mainland. The agricultural regions are Northeast China, North China, Northwest China, and South China. 
interviewers copied the paper versions of questionnaires to electronic files and returned both of them; (4) data entry and cleaning: we distributed 850 questionnaires and obtained 779 valid questionnaires coving 141 counties and these questionnaires included 347 for corn, 288 for wheat and 375 for rice. The invalid questionnaires referred to these without fertilization status or with the values being threefold standard deviations more than the national mean of mineral $\mathrm{N}$ fertilization rates. All survey data were copied from MS Word to MS Excel files for further analysis.

\subsection{Field data source}

Multiple cropping systems are popular in Chinese cropland especially in North and South China. For single cropping systems, the sown area in a year equals the cultivated area, while multiple cropping systems can double or triple the cultivated area. When we discuss the GHG emission and mitigation of $\mathrm{N}$ fertilization, the study area is constricted to the cropland where corn, wheat or rice are planted $\left(A_{i}\right)$, i.e. the effective cultivated area for the three crops. Therefore, $A_{i}$ was calculated according to Lu et al. (2009) as follows:

$\mathrm{A}_{i}=\mathrm{CAT}_{i} *\left(\sum \mathrm{SA}_{i j}\right) / \mathrm{SAT}_{i}$

where for province $i, \mathrm{~A}_{i}$ is the cropland area with three crops; $\mathrm{CAT}_{i}$ is the total cultivated area; $\mathrm{SA}_{i j}$ is the sown area of crop $j$; crop $j$ is corn, wheat or rice; and $\mathrm{SAT}_{i}$ is the total sown area of all three crops in 2011 (NBS, 2012). All units of these areas are $10^{3}$ ha.

\subsection{Scenario design}

Two scenarios of $\mathrm{N}$ fertilization were designed in this study: the current situation (CS) scenario based on our survey and the fertilizer recommendation (FR) scenario based on the Recommendation. The Recommendation provides ranges of suitable $\mathrm{N}$ fertilization in accordance with producing region, cropping system and crop yields (MOA, 2013).

\subsection{Data analysis}

\subsection{1. $N$ fertilization amount}

The amount of $\mathrm{N}$ fertilizer application per unit area for one crop in each province was calculated using Formula (3):

$\mathrm{ANR}_{i j}=\sum_{n}\left(\sum_{p}\left(\mathrm{CN}_{F_{p}} \cdot \mathrm{AF}_{n F_{p}}\right)\right) / \mathrm{M}_{i j}$

where for province $i, \mathrm{ANR}_{i j}\left(\mathrm{~kg} \mathrm{~N} \mathrm{ha}^{-1}\right)$ is the amount of $\mathrm{N}$ fertilizer applied per sown hectare of crop $j$, crop $j$ is corn, wheat or rice; $\mathrm{CN}_{F p}$ $\left(\mathrm{kg} \mathrm{N} \mathrm{kg}^{-1}\right)$ is the $\mathrm{N}$ content of fertilizer $F_{p} ; \mathrm{AF}_{n F p}\left(\mathrm{~kg} \mathrm{ha}^{-1}\right)$ is the amount of fertilizer $F_{p}$ application in 2011 for the $n$th farmer; and $\mathrm{M}_{i j}$ is the number of farmers investigated for the CS scenario. $F_{p}$ and $\mathrm{AF}_{F p}$ are showed in Table A1 in Appendix.

Therefore, the total amount of $\mathrm{N}$ fertilizer application (TNR, Mt $\mathrm{N} \mathrm{yr}^{-1}$ ) was calculated in each province using Formula (4):

$\mathrm{TNR}_{i}=\sum_{j}\left(\mathrm{ANR}_{i j} * \mathrm{SA}_{i j}\right) / 10^{6}$

where $\mathrm{SA}_{i j}\left(10^{3} \mathrm{ha}\right)$ is the sown area of crop $j$ in province $i$.

Subsequently for the CS and FR scenarios, the annual amount of $\mathrm{N}$ fertilizer application for the three cereals per unit cropland area in each province $\left(\mathrm{N}_{i}, \mathrm{~kg} \mathrm{~N} \mathrm{ha}^{-1} \mathrm{yr}^{-1}\right)$ was obtained using Formula (5):

$\mathrm{N}_{i}=\mathrm{TNR}_{i} * 10^{3} / \mathrm{A}_{i}$

\subsection{2. $\mathrm{CO}_{2}$ emission}

The production and transport of mineral $\mathrm{N}$ fertilizer require fossil fuel and emit $\mathrm{CO}_{2}$ to the atmosphere. These $\mathrm{CO}_{2}$ emissions were calculated using Formula (6):

$\mathrm{EPT}_{i}=(\mathrm{EPC}+\mathrm{ETC}) * \mathrm{TNR}_{i} / 10^{3}$

where $\mathrm{EPT}_{i}\left(\mathrm{Tg} \mathrm{Cyr}^{-1}\right)$ is the $\mathrm{CO}_{2}$-carbon (C) emission of mineral $\mathrm{N}$ fertilizer production and transport; EPC is the production emission coefficient of $2.143 \mathrm{t} \mathrm{C} \mathrm{t} \mathrm{N}^{-1}$, provided by Chen et al. (2015); and ETC is the transport emission coefficient of $0.03 \mathrm{t} \mathrm{C} \mathrm{t} \mathrm{N}^{-1}$, obtained from Zhang et al. (2013).

\subsection{3. $\mathrm{N}_{2} \mathrm{O}$ emission}

The $\mathrm{N}$ fertilizer application to cropland increases $\mathrm{N}_{2} \mathrm{O}$ flux from soil. The direct $\mathrm{N}_{2} \mathrm{O}$ flux was estimated according to the method of IPCC (2006) and converted to $\mathrm{CO}_{2}-\mathrm{C}$ equivalents (EA, Tg Ceq $\mathrm{yr}^{-1}$ ) using the global warming potential with a time span of 100 years:

$\mathrm{EA}_{i}=\mathrm{TNR}_{i} * \mathrm{EFd}_{i} / 28 * 44 * 298 / 44 * 12 * 10^{-3}$

where $\mathrm{EFd}_{i}$ is the $\mathrm{N}_{2} \mathrm{O}$ emission coefficient in province $i$. The coefficients are $0.0101,0.00483,0.00483$ and 0.0119 in Northeast, North, Northwest and South China, respectively (Lu et al., 2008; Zheng et al., 2002).

\subsubsection{Soil carbon sequestration}

$\mathrm{N}$ fertilization can increase soil $\mathrm{C}$ storage by improving crop yield, followed by root and residue input. However, excessive $\mathrm{N}$ application does not increase yield and soil organic $C$ content compared with optimum application (Brown et al., 2014; Hawkesford, 2014). Therefore, we assumed that the $\mathrm{N}$ fertilization in the FR scenario was sufficient for crop growth close to the maximum and hence SCS remained similar in both scenarios.

According to Lu et al. (2008, 2009), the SCS rate was suggested to have linear relationship with the $\mathrm{N}$ fertilization amount up to optimum fertilization (similar to FR scenario). Therefore, SCS was obtained using Eq. (8):

$\mathrm{SCS}_{i}=\left(\mathrm{a}_{i} * \mathrm{~N}_{i}+\mathrm{b}_{i}\right) * \mathrm{~A}_{i} / 10^{6}$

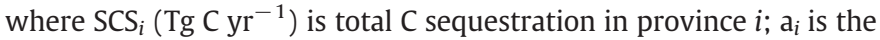
slope; and $\mathrm{b}_{i}$ is the intercept of the linear equation, with $\mathrm{a}$ and $\mathrm{b}$ given respectively as follows: 1.7385 and -104.03 for Northeast, 0.5286 and 1.5973 for North, 0.6352 and -1.0834 for Northwest and 1.1054 and 0 for South China (Lu et al., 2009).

\subsubsection{Net mitigation potential}

The total effective GHG emission in province $i\left(\mathrm{TEGE}_{i}, \mathrm{Tg}_{\mathrm{Ceq} \mathrm{yr}^{-1}}\right.$ ) was evaluated using Formula (9):

$\mathrm{TEGE}_{i}=\mathrm{EA}_{i}+\mathrm{EPT}_{i}-\mathrm{SCS}_{i}$

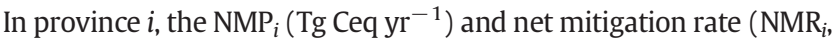
$\mathrm{kg}$ Ceq ha $\mathrm{hr}^{-1} \mathrm{yr}^{-1}$ ) in the FR scenario were calculated as indicated in Formulae (10) and (11):

$\mathrm{NMP}_{i}=\mathrm{TEGE}_{C S i}-\mathrm{TEGE}_{F R i}$

$\mathrm{NMR}_{i}=\mathrm{NMP}_{i} / \mathrm{A}_{i}$

where $\mathrm{TEGE}_{C S}$ and $\mathrm{TEGE}_{F R}$ are TEGE in the CS and FR scenarios in province $i$, respectively.

\subsubsection{Statistical analysis}

To test the validity of the survey, a paired-sample $t$-test was conducted between values from the field survey and the China Statistical Yearbook (NBS, 2012) for yields of corn, wheat and rice, respectively there were no significant differences between them. It was impossible 
to validate $\mathrm{N}$ fertilization rates with farmers' purchase records, but a $t$-test showed no significant difference between annual $\mathrm{N}$ fertilization rates in counties surveyed in the present study and statistical data for 2010 from Agricultural Information Institution, Chinese Academy of Agricultural Sciences. We also compared the annual $\mathrm{N}$ fertilization in the three crops in 31 provinces between this study and other studies (Fig.5). Paired-sample $t$-tests were also performed to test the effects of the Recommendation on $\mathrm{N}$ fertilizer application rate and amount and TEGE. Difference at $P<0.05$ was considered significant for $t$-tests.

An uncertainty of quantity could be expressed as a $95 \%$ confidence interval of individual estimate (IPCC, 2000). In this study, we only quantitatively estimated the uncertainties related to the amount of $\mathrm{N}$ fertilization surveyed. The uncertainty of $\mathrm{N}_{i}\left(\mathrm{U}_{\mathrm{Ni}}, \mathrm{kg} \mathrm{N} \mathrm{ha}^{-1} \mathrm{yr}^{-1}\right)$, i.e., the $95 \%$ confidence interval of $\mathrm{N}_{i}$, was calculated with Formula (12):

$\mathrm{U}_{N i}=\sqrt{\sum_{j}\left(\mathrm{SA}_{i j} \cdot \mathrm{U}_{N i j} / \mathrm{A}_{i}\right)^{2}}$

where for province $i, \mathrm{U}_{N i j}$ is $95 \%$ confidence interval of $\mathrm{ANR}_{i j}$ of crop $j$. Furthermore, the uncertainties of $\mathrm{EPT}_{i}\left(\mathrm{U}_{E P T i}\right), \mathrm{EA}_{i}\left(\mathrm{U}_{E A i}\right)$ and $\mathrm{SCS}_{i}$ $\left(\mathrm{U}_{S C S i}\right)$ were estimated using Formulae (13)-(15), respectively and showed in Table A2 in Appendix:

$\mathrm{U}_{E P T i}=\sqrt{\left((\mathrm{EPC}+\mathrm{ETC}) \cdot \mathrm{A}_{i} \cdot 10^{6}\right)^{2} \cdot \mathrm{U}_{N i}^{2}}$

$\mathrm{U}_{E A i}=\sqrt{\left(\mathrm{EFd}_{i} \cdot \mathrm{A}_{i} / 28 \cdot 298 \cdot 12 \cdot 10^{6}\right)^{2} \cdot \mathrm{U}_{N i}^{2}}$

$\mathrm{U}_{S C S i}=\sqrt{\left(\mathrm{a}_{i} \cdot \mathrm{A}_{i} \cdot 10^{6}\right)^{2} \cdot \mathrm{U}_{N i}^{2}}$
Finally, the uncertainty of NMP $\left(\mathrm{U}_{N M P i}\right)$ was calculated using Formula (16) (IPCC, 2000):

$\mathrm{U}_{N M P i}=\sqrt{\sum\left(\mathrm{U}_{X i} \text { in } \mathrm{CS}\right)^{2}+\sum\left(\mathrm{U}_{X i} \text { in FR }\right)^{2}}$

where $\mathrm{U}_{X C S i}$ in $\mathrm{CS}$ and $\mathrm{U}_{X F R i}$ in FR represents the uncertainties of $\mathrm{EPT}_{i}, \mathrm{EA}_{i}$ and $\mathrm{SCS}_{i}$ in CS and FR scenarios, respectively.

\section{Results}

\section{1. $N$ fertilization amount}

In 2011, the cropland area of corn, wheat and rice was $66 \mathrm{M}$ ha with a total annual $\mathrm{N}$ fertilization of $19.1 \pm 1.2 \mathrm{Mt} \mathrm{N} \mathrm{yr}^{-1}$ throughout China in the CS scenario (Table 1). The amounts were 2.6 (Northeast), 5.3 (North), 1.5 (Northwest) and $9.5 \mathrm{Mt} \mathrm{N} \mathrm{yr}^{-1}$ (South). There were seven provinces with $\mathrm{N}$ fertilization of more than $1 \mathrm{Mt} \mathrm{N} \mathrm{yr}^{-1}$ in China. In the FR scenario, the total $\mathrm{N}$ application significantly decreased by about $37 \%$ to $11.9 \pm 0.3 \mathrm{Mt} \mathrm{N} \mathrm{yr}^{-1}$ in China $(P<0.001)$. The annual decreases were ranked as $5.6 \mathrm{Mt}$ (South) > $3.7 \mathrm{Mt}$ (North) $>1.8 \mathrm{Mt}$ (Northeast) $>0.8 \mathrm{Mt}$ (Northwest). The $\mathrm{N}$ application amount exceeded $1 \mathrm{Mt} \mathrm{N} \mathrm{yr}^{-1}$ only in Henan Province. These results indicated that though there were overlaps between the CS and FR scenarios for some provinces (Table 1), $\mathrm{N}$ fertilization overuse was widespread across China in the CS scenario.

Our results showed that the spatial patterns of $\mathrm{N}$ fertilization amount per unit area $\left(\mathrm{N}_{i}\right)$ varied greatly across China (Table 1 , Fig. 2a). In the CS scenario, the average $\mathrm{N}_{i}$ was 187 (Northeast), 268 (North), 227 (Northwest) and $380 \mathrm{~kg} \mathrm{~N} \mathrm{ha}^{-1} \mathrm{yr}^{-1}$ (South). The $\mathrm{N}_{i}$ exceeded $300 \mathrm{~kg} \mathrm{~N} \mathrm{ha}^{-1} \mathrm{yr}^{-1}$ in 14 provinces: 12 in South and two in North China. In the FR scenario, the average $\mathrm{N}_{i}$ reduced to 123

Table 1

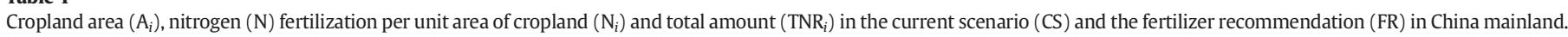

\begin{tabular}{|c|c|c|c|c|c|c|}
\hline \multirow[t]{2}{*}{ Cropping region } & \multirow[t]{2}{*}{ Province } & \multirow{2}{*}{$\frac{\mathrm{A}_{i}}{(\mathrm{k} \text { ha })}$} & \multicolumn{2}{|c|}{$\mathrm{N}_{i}\left(\mathrm{~kg} \mathrm{~N} \mathrm{ha}^{-1} \mathrm{yr}^{-1}\right)$} & \multicolumn{2}{|c|}{$\mathrm{TNR}_{i}\left(\mathrm{Mt} \mathrm{N} \mathrm{yr}^{-1}\right)$} \\
\hline & & & CS & FR & CS & FR \\
\hline \multirow[t]{3}{*}{ Northeast } & Liaoning & 2760 & $238 \pm 167$ & $141 \pm 20$ & $0.66 \pm 0.46$ & $0.39 \pm 0.03$ \\
\hline & Jilin & 4058 & $240 \pm 29$ & $130 \pm 27$ & $0.97 \pm 0.12$ & $0.53 \pm 0.06$ \\
\hline & Heilongjiang & 7579 & $140 \pm 56$ & $113 \pm 19$ & $1.06 \pm 0.43$ & $0.86 \pm 0.07$ \\
\hline \multirow[t]{7}{*}{ North } & Beijing & 152 & $314 \pm 43$ & $164 \pm 21$ & $0.05 \pm 0.01$ & $0.02 \pm 0.002$ \\
\hline & Tianjin & 276 & $207 \pm 50$ & $135 \pm 14$ & $0.06 \pm 0.01$ & $0.04 \pm 0.002$ \\
\hline & Hebei & 3971 & $289 \pm 49$ & $199 \pm 39$ & $1.15 \pm 0.19$ & $0.79 \pm 0.08$ \\
\hline & Shanxi & 2518 & $138 \pm 24$ & $111 \pm 19$ & $0.35 \pm 0.06$ & $0.28 \pm 0.02$ \\
\hline & Inner Mongolia & 3345 & $162 \pm 31$ & $111 \pm 24$ & $0.54 \pm 0.10$ & $0.37 \pm 0.04$ \\
\hline & Shandong & 4644 & $289 \pm 35$ & $186 \pm 20$ & $1.34 \pm 0.16$ & $0.86 \pm 0.05$ \\
\hline & Henan & 4996 & $370 \pm 52$ & $274 \pm 68$ & $1.85 \pm 0.26$ & $1.37 \pm 0.17$ \\
\hline \multirow[t]{5}{*}{ Northwest } & Shaanxi & 2359 & $239 \pm 19$ & $119 \pm 26$ & $0.56 \pm 0.04$ & $0.28 \pm 0.03$ \\
\hline & Gansu & 1935 & $185 \pm 30$ & $102 \pm 23$ & $0.36 \pm 0.06$ & $0.20 \pm 0.02$ \\
\hline & Qinghai & 113 & $248 \pm 37$ & $113 \pm 21$ & $0.03 \pm 0.004$ & $0.01 \pm 0.001$ \\
\hline & Ningxia & 454 & $296 \pm 105$ & $146 \pm 26$ & $0.13 \pm 0.05$ & $0.07 \pm 0.01$ \\
\hline & Xinjiang & 1553 & $241 \pm 90$ & $182 \pm 19$ & $0.37 \pm 0.14$ & $0.28 \pm 0.02$ \\
\hline \multirow[t]{16}{*}{ South } & Shanghai & 104 & $441 \pm 40$ & $318 \pm 28$ & $0.05 \pm 0.004$ & $0.03 \pm 0.001$ \\
\hline & Jiangsu & 2969 & $505 \pm 102$ & $303 \pm 45$ & $1.50 \pm 0.30$ & $0.90 \pm 0.07$ \\
\hline & Zhejiang & 779 & $323 \pm 49$ & $220 \pm 48$ & $0.25 \pm 0.04$ & $0.17 \pm 0.02$ \\
\hline & Anhui & 3450 & $418 \pm 46$ & $227 \pm 47$ & $1.44 \pm 0.16$ & $0.78 \pm 0.08$ \\
\hline & Fujian & 518 & $506 \pm 135$ & $237 \pm 51$ & $0.26 \pm 0.07$ & $0.12 \pm 0.01$ \\
\hline & Jiangxi & 1728 & $345 \pm 55$ & $268 \pm 67$ & $0.60 \pm 0.10$ & $0.46 \pm 0.06$ \\
\hline & Hubei & 2096 & $382 \pm 53$ & $262 \pm 45$ & $0.80 \pm 0.11$ & $0.55 \pm 0.05$ \\
\hline & Hunan & 2000 & $466 \pm 76$ & $304 \pm 71$ & $0.93 \pm 0.15$ & $0.61 \pm 0.07$ \\
\hline & Guangdong & 1310 & $402 \pm 37$ & $222 \pm 46$ & $0.53 \pm 0.05$ & $0.29 \pm 0.03$ \\
\hline & Guangxi & 1861 & $270 \pm 33$ & $165 \pm 28$ & $0.50 \pm 0.06$ & $0.31 \pm 0.03$ \\
\hline & Hainan & 297 & $255 \pm 36$ & $128 \pm 20$ & $0.08 \pm 0.01$ & $0.04 \pm 0.003$ \\
\hline & Chongqing & 846 & $353 \pm 148$ & $201 \pm 17$ & $0.30 \pm 0.13$ & $0.17 \pm 0.01$ \\
\hline & Sichuan & 2879 & $364 \pm 245$ & $205 \pm 30$ & $1.05 \pm 0.70$ & $0.59 \pm 0.04$ \\
\hline & Guizhou & 1543 & $233 \pm 136$ & $125 \pm 16$ & $0.36 \pm 0.21$ & $0.19 \pm 0.01$ \\
\hline & Yunnan & 2660 & $357 \pm 93$ & $136 \pm 14$ & $0.95 \pm 0.25$ & $0.36 \pm 0.02$ \\
\hline & Tibet & 64 & $133 \pm 209$ & $106 \pm 19$ & $0.01 \pm 0.01$ & $0.01 \pm 0.001$ \\
\hline Country & & 65,818 & $290 \pm 18$ & $181 \pm 8$ & $19.08 \pm 1.17$ & $11.94 \pm 0.3$ \\
\hline
\end{tabular}

The values of $\mathrm{N}_{i}$ and $\mathrm{TNR}_{i}$ are showed as mean $\pm 95 \%$ confidence interval. 

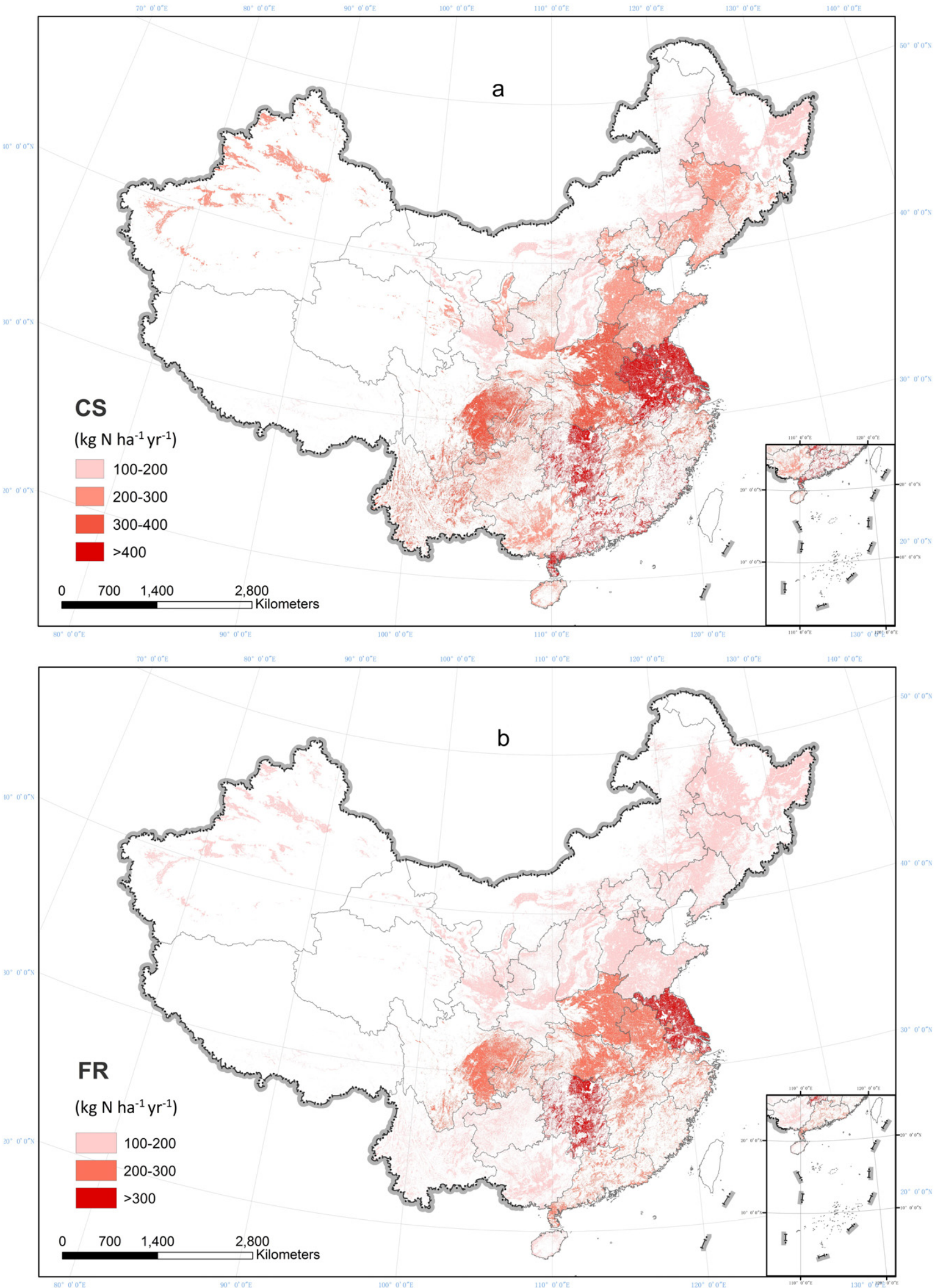

Fig. 2. Nitrogen fertilizer amount ( $\mathrm{kg} \mathrm{N} \mathrm{ha}^{-1} \mathrm{yr}^{-1}$ ) under the current situation (CS) scenario (a) and fertilizer recommendation (FR) scenario (b) in Chinese cropland. 
(Northeast), 188 (North), 131 (Northwest) and $223 \mathrm{~kg} \mathrm{~N} \mathrm{ha}^{-1} \mathrm{yr}^{-1}$ (South) (Table 1, Fig. 2b). The $\mathrm{N}_{i}$ was lower than $300 \mathrm{~kg} \mathrm{~N} \mathrm{ha}^{-1} \mathrm{yr}^{-1}$ for all provinces except Shanghai, Hunan and Jiangsu.

\section{2. $\mathrm{CO}_{2}$ emission}

The $\mathrm{CO}_{2}$ emission was $40.9 \pm 2.5 \mathrm{Tg} \mathrm{C} \mathrm{yr}^{-1}$ from production and transport of $\mathrm{N}$ fertilizer in the CS scenario in China (Fig. 3, Table A2 in Appendix). These emissions exceeded $2.5 \mathrm{Tg} \mathrm{C} \mathrm{yr}^{-1}$ in Henan, Jiangsu, Anhui and Shandong (3.96, 3.21, 3.09 and $2.88 \mathrm{Tg} \mathrm{C} \mathrm{yr}^{-1}$, respectively). In the FR scenario, the total emissions decreased by about $37 \%$ to $25.6 \pm$ $1.2 \mathrm{Tg} \mathrm{C} \mathrm{yr}{ }^{-1}$ in China. The emissions decreased by more than $1 \mathrm{Tg} \mathrm{C} \mathrm{yr}^{-1}$ in Henan, Shandong, Anhui, Jiangsu and Yunnan.

\section{3. $\mathrm{N}_{2} \mathrm{O}$ emission}

The total $\mathrm{N}_{2} \mathrm{O}$ emission was $22.2 \pm 1.6 \mathrm{Tg} \mathrm{Ceq} \mathrm{yr}^{-1}$ in the CS scenario

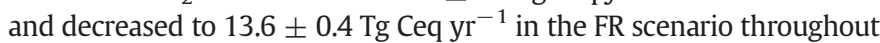
China (Fig. 3, Table A2 in Appendix). This emission decrease was more than $10 \%$ for all provinces. The emission decrease exceeded $1 \mathrm{Tg}^{\mathrm{Ceq}} \mathrm{yr}^{-1}$ in Heilongjiang, Jiangsu and Anhui.

\subsection{Soil carbon sequestration}

The SCS was $11.1 \pm 0.7 \mathrm{Tg} \mathrm{C} \mathrm{yr}^{-1}$ in both scenarios due to $\mathrm{N}$ fertilization throughout China (Fig. 3, Table A2 in Appendix). The SCS was more than $0.51 \mathrm{TgC} \mathrm{yr}^{-1}$ in two provinces in Northeast China (Heilongjiang and Jilin), three in North China (Henan, Shandong and Hebei) and six in South China (Jiangsu, Anhui, Hunan, Sichuan, Hubei and Jiangxi). The sum of SCS in these provinces represented about $68 \%$ of China's se-

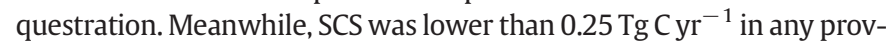
ince of Northwest China.

\subsection{Net mitigation potential}

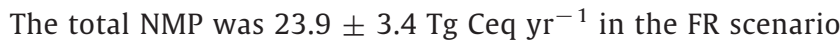

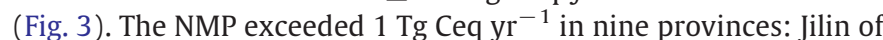
Northeast China; Henan, Shandong and Hebei of North China; and Anhui, Jiangsu, Yunnan, Sichuan and Hunan of South China. The sum of NMP in these provinces contributed about $62 \%$ of the national NMP. The average NMR was $360 \mathrm{~kg} \mathrm{Ceq} \mathrm{ha}^{-1} \mathrm{yr}^{-1}$ in China with a range of 72-974 kg Ceq ha-1 $\mathrm{yr}^{-1}$ across all provinces (Fig. 4). The NMR was more than $500 \mathrm{~kg} \mathrm{ha}^{-1} \mathrm{yr}^{-1}$ in seven provinces of South China: Jiangsu, Anhui, Fujian, Hunan, Guangdong, Sichuan and Yunnan.

\section{Discussion}

\section{1. $N$ fertilization amount}

Our results indicate a spatial variation and overuse of $\mathrm{N}$ fertilization in corn, wheat and rice across China. The results were supported by other studies of fertilization of these three crops (Chai et al., 2013; Huang and Tang, 2010; Lu et al., 2009) (Fig. 5). The annual N fertilization in these other studies, calculated using the method of the present study, showed a very similar trend among 31 provinces, though the national-

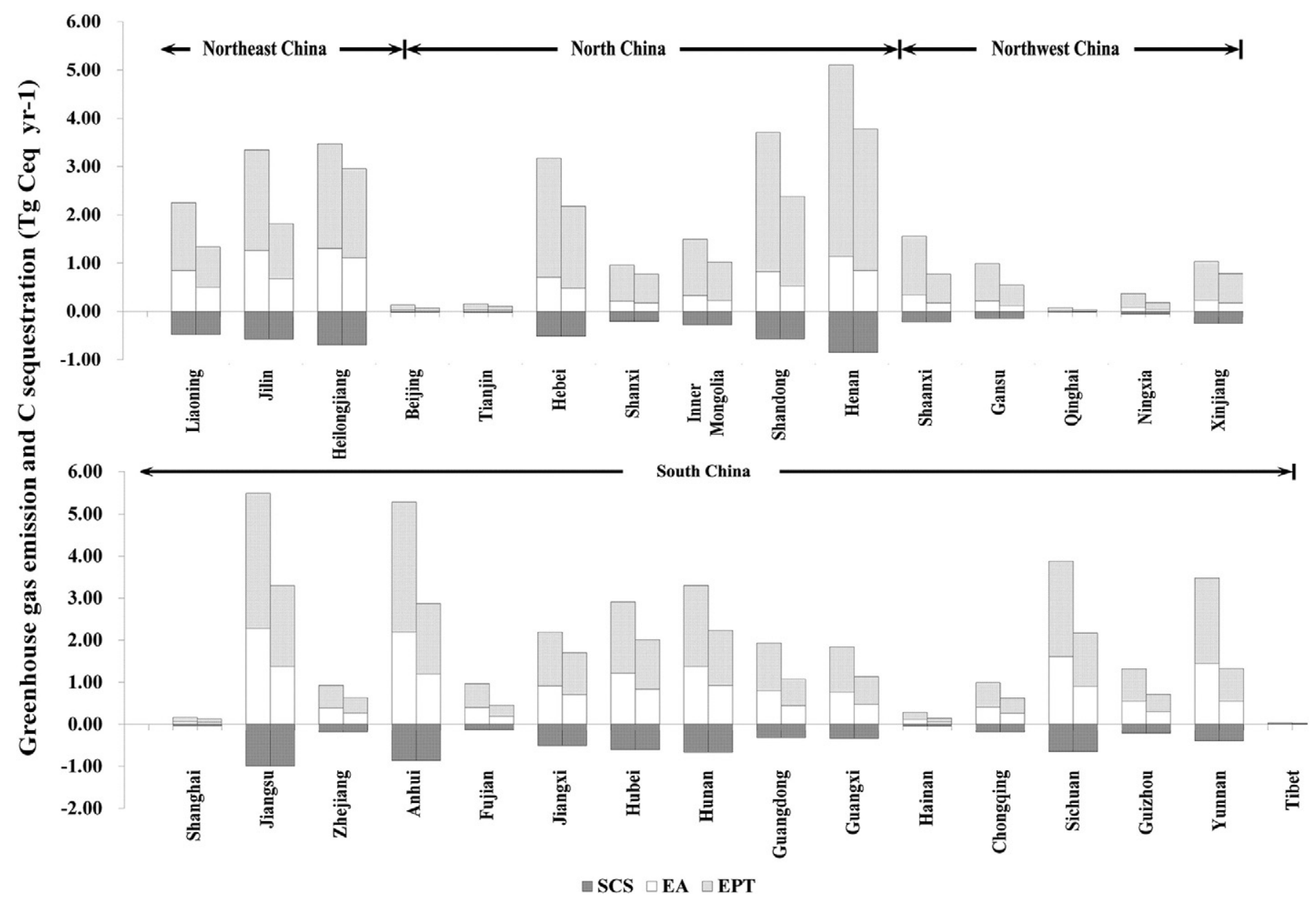

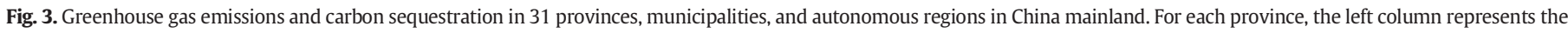

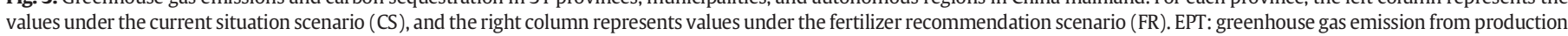

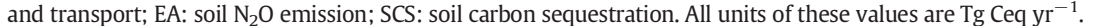




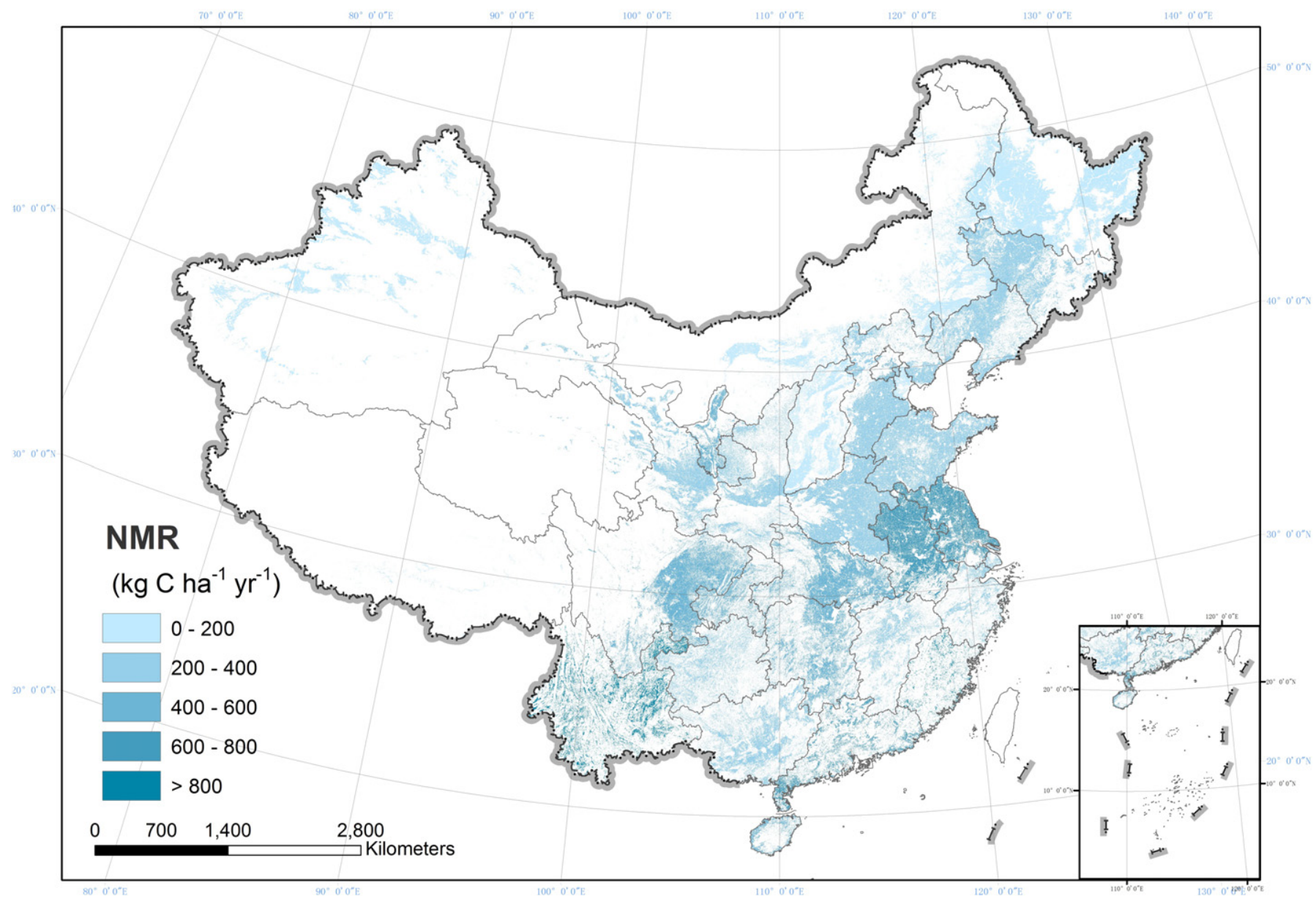

Fig. 4. Net mitigation rate (NMR, $\mathrm{kg} \mathrm{Ceq} \mathrm{ha}^{-1} \mathrm{yr}^{-1}$ ) in fertilizer recommendation scenario in China cropland.

scale rate in the present study (290 $\mathrm{kg} \mathrm{N} \mathrm{ha}^{-1} \mathrm{yr}^{-1}$ ) was higher than 287 (Chai et al. 2013), 272 (Huang and Tang 2010) and $212 \mathrm{~kg} \mathrm{~N}^{-1-}$ $\mathrm{yr}^{-1}$ (Lu et al., 2009). Therefore, our survey was applicable to $\mathrm{N}$ fertilization in China at a large spatial scale. In this study, the annual $\mathrm{N}$ fertilization in South and North China was higher than in Northeast and Northwest China, which is consistent with the conclusion of Tian et al. (2011). This higher annual $\mathrm{N}$ fertilization is mainly attributed to multiple cropping systems and higher economic levels in South and North China (Zhang et al., 2013). Meanwhile, excessive fertilization is widespread in Chinese croplands (Gao 2008; Zhang et al., 2008). From 2000 to 2011, the total $\mathrm{N}$ fertilizer applied to the three crops increased from $16 \mathrm{Mt} \mathrm{N} \mathrm{yr}^{-1}$ (Huang and Tang, 2010) to $19.1 \pm 1.2 \mathrm{Mt} \mathrm{N} \mathrm{yr}^{-1}$ as determined in the present study. Ju et al. (2009) indicates that $\mathrm{N}$ fertilization could be reduced by $30 \%-60 \%$ without yield loss in South and

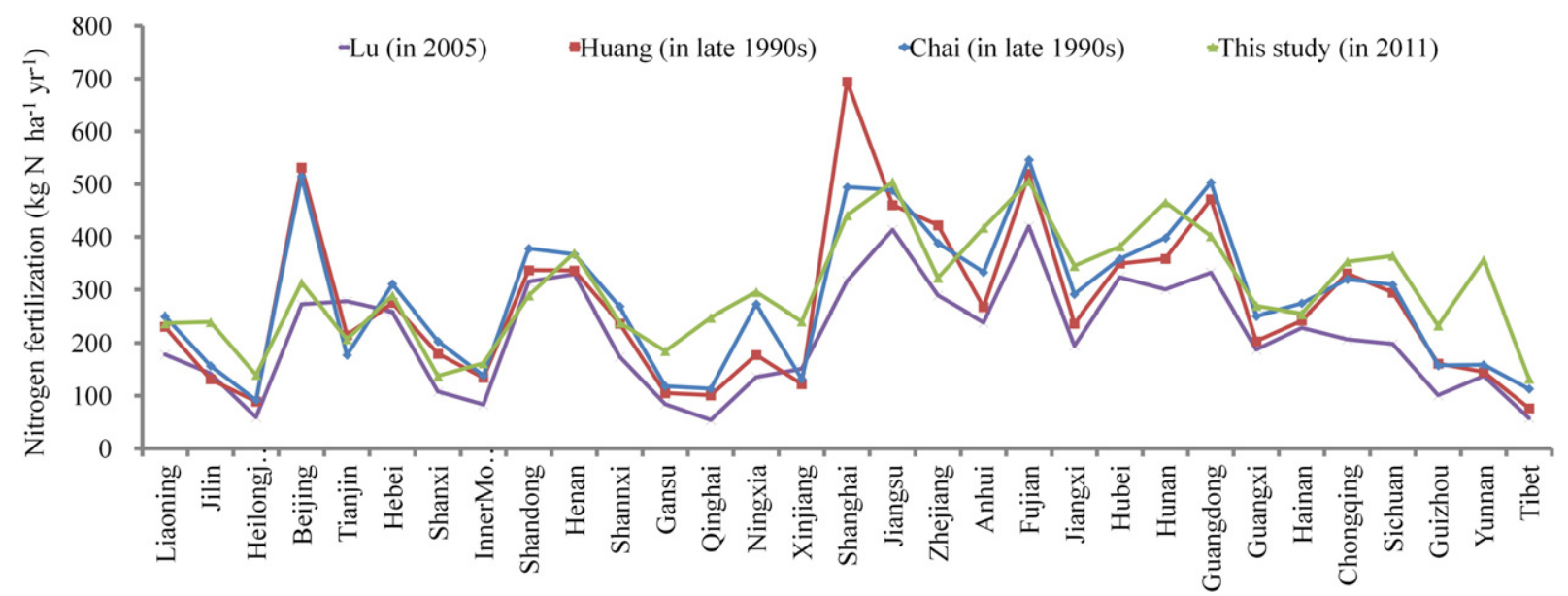

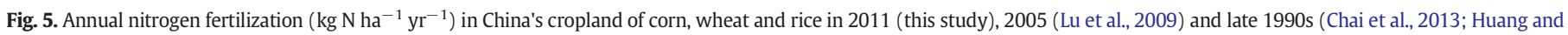
Tang, 2010). 
North China based on field experiments. During 2005-2007, an on-farm study also implied that optimal $\mathrm{N}$ fertilization decreased from 369 to $117 \mathrm{~kg} \mathrm{~N} \mathrm{ha}^{-1} \mathrm{yr}^{-1}$ without yield loss during wheat growing season, together with a reduction in $\mathrm{N}$ loss from 123 to $30 \mathrm{~kg} \mathrm{~N} \mathrm{ha}^{-1} \mathrm{yr}^{-1}$ in the North China Plain (Cui et al., 2011). According to quantitative relationships among core $\mathrm{N}$ fluxes in the crop root zone, the suitable $\mathrm{N}$ fertilization rate is $60 \%$ of the conventional rate in the North China Plain (Ju and Christie, 2011). These results are consistent with our estimation that the annual $\mathrm{N}$ fertilization in the FR scenario could be reduced by $35 \%$ compared to the CS scenario in the North China Plain. Therefore, implementation of the Recommendation might significantly reduce $\mathrm{N}$ fertilization without crop yield loss in China.

Our survey was across typical agricultural regions of China, but some factors may introduce uncertainties to the $\mathrm{N}$ fertilization estimation throughout the cropland. First, though annual $\mathrm{N}$ fertilization showed a similar trend among different studies, there were some exceptions due to sampling methods (Fig. 5). In the case of Shandong province, the average $\mathrm{N}$ fertilization of $289 \mathrm{~kg} \mathrm{~N} \mathrm{ha}^{-1} \mathrm{yr}^{-1}$ in this study was a litthe more than that of $252 \mathrm{~kg} \mathrm{~N}^{-1}$ only for corn production in 2009 for 474 non-trained farmers (Jia et al., 2013). Furthermore, we also found that $\mathrm{N}$ fertilization for some farmers was lower than the national recommendation (Table 1). Therefore, it would be better if more surveys were conducted in the future. Second, other inputs of N sources, including straw and manure, can also increase soil $\mathrm{N}$ content (Basche et al., 2014; Maillard and Angers, 2014). Hence, $\mathrm{N}$ fertilization in the FR scenario may be overestimated compared to the optimum $\mathrm{N}$ fertilization. Finally, estimation in only three crops cannot draw a full picture of $\mathrm{N}$ fertilization in all cropland of China. Therefore, further research is required to widely investigate $\mathrm{N}$ fertilization across China, including inputs of other $\mathrm{N}$ sources and crops.

\section{2. $\mathrm{CO}_{2}$ emission}

The reduction of $\mathrm{N}$ fertilization would also decrease the $\mathrm{CO}_{2}$ emissions from production and transport of $\mathrm{N}$ fertilizer. Our study shows that this emission contributed to $60 \%$ of the total GHG emissions from $\mathrm{N}$ fertilization in the CS scenario. The NMP for transport and production

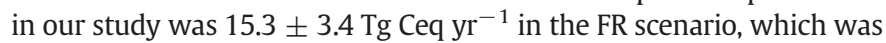

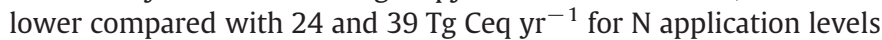
of 150 and $110 \mathrm{~kg} \mathrm{~N} \mathrm{ha}^{-1}$, respectively, in Chinese cropland using the same three crops (Chai et al., 2013). The production of $\mathrm{N}$ fertilizer in China consumes more fossil fuel than in developed countries due to low energy efficiency and outdated technology (Kahrl et al., 2010). Hence, improvements in $\mathrm{N}$ fertilizer production technology could mitigate $44 \mathrm{Tg} \mathrm{Ceq} \mathrm{yr}^{-1}$ in $\mathrm{N}$ fertilization to Chinese cropland using similar crops (Zhang et al., 2013). These studies indicate that implementation of the Recommendation, together with technical improvements in $\mathrm{N}$ fertilizer production, will mitigate even more $\mathrm{CO}_{2}$ emissions from production and transport in China.

\section{3. $\mathrm{N}_{2} \mathrm{O}$ emission}

Soil with $\mathrm{N}$ fertilizer input is one source of $\mathrm{N}_{2} \mathrm{O}$ emissions on a global scale (Linquist et al., 2012; Venterea et al., 2011). Six field trials of wheat growth showed a linear relationship between mineral $\mathrm{N}$ fertilization (0-400 $\mathrm{kg} \mathrm{N} \mathrm{ha}^{-1}$ ) and cumulative $\mathrm{N}_{2} \mathrm{O}$ emissions measured using a closed chamber method in Germany (Lebender et al., 2014). Compared to no $\mathrm{N}$ addition in rice paddies, the $\mathrm{N}$ fertilization of 150 and $250 \mathrm{~kg} \mathrm{~N} \mathrm{ha}^{-1}$ increased $\mathrm{N}_{2} \mathrm{O}$ emission by 2.5 and 6 times, respectively, during 2005-2007 in the Yangtze River Delta in China (Yao et al., 2012). A meta-analysis showed that the $\mathrm{N}$ fertilization of $181 \mathrm{~kg} \mathrm{~N} \mathrm{ha}^{-1}$ increased $\mathrm{N}_{2} \mathrm{O}$ emission by $78 \%$ compared with controls in China's croplands (Sun et al. 2015). Using the DNDC model, the fertilizer-induced $\mathrm{N}_{2} \mathrm{O}$ emission was estimated at $25 \mathrm{Tg} \mathrm{Ceq} \mathrm{yr}^{-1}$ in Chinese agricultural soils in 1990 (Wang and Li, 2000). Lu and Tian (2013) estimated that

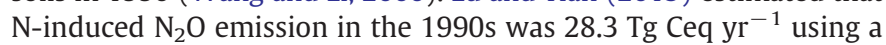

coupled biogeochemical model in Chinese cropland. The estimation of $\mathrm{N}_{2} \mathrm{O}$ emission $\left(22.2 \pm 1.6{\mathrm{Tg} \mathrm{Ceq} \mathrm{yr}^{-1}}^{-1}\right)$ in the present study (CS scenario) was lower than that in these other studies. The reason is that the study of Wang and Li (2000) aimed at all agricultural soils and the study of Lu and Tian (2013) at cropland with six crops, while we focused on croplands with only three crops. Our results showed that $\mathrm{N}_{2} \mathrm{O}$ emission could be mitigated by $8.6 \pm 1.7 \mathrm{Tg}$ Ceq $\mathrm{yr}^{-1}$ under a $37 \%$ reduction of $\mathrm{N}$ fertilization, which represents about $36 \%$ of the NMP in the FR scenario. A smaller

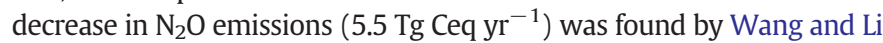
(2000) under a 50\% reduction of $\mathrm{N}$ fertilization (about $8.2 \mathrm{Mt}$ ) in 1990; while in the study of Chai et al. (2013), the mitigation potential in the

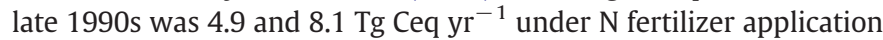
levels of 150 and $110 \mathrm{~kg} \mathrm{~N} \mathrm{ha}^{-1}$, respectively, in China's cropland. These mitigation potentials differed between the present study and other studies due to different estimation methods of $\mathrm{N}_{2} \mathrm{O}$ emission and periods of $\mathrm{N}$ fertilization; however, all these studies demonstrate that a reduction of excessive $\mathrm{N}$ fertilization can mitigate $\mathrm{N}_{2} \mathrm{O}$ emissions from cropland.

\subsection{Soil carbon sequestration}

The $\mathrm{N}$ fertilization can increase soil C storage by increasing crop productivity and resultant residue input (Lu et al., 2011b), but crop yield is also determined by photosynthetic efficiency, water supply and genetic properties (Hawkesford, 2014). An N fertilization threshold that enables crops to reach maximum yields exists. The fertilization exceeding the threshold does not increase yield and improve $C$ sequestration rate compared to optimal fertilization (Hawkesford, 2014; Brown et al., 2014). The SCS induced by $\mathrm{N}$ fertilization in the present study (11.1 \pm $0.7 \mathrm{Tg} \mathrm{C} \mathrm{yr}^{-1}$ ) was slightly lower than the $12 \mathrm{Tg} \mathrm{C} \mathrm{yr}^{-1}$ of Lu et al. (2009). This difference can be explained in two ways: one is that the $\mathrm{N}$ fertilization of the Recommendation in the present study was lower due to being based on national testing of soil for formulated fertilization technology (Chen et al., 2014), and the other is that excessive N fertilization cannot sequester more $\mathrm{C}$ to the soil in the present study.

Our result indicated that SCS presented a consistent spatial pattern with $\mathrm{N}$ fertilization across China. This result was also found in the effect of N deposition on SCS in Chinese terrestrial ecosystems (Lu et al., 2011a). The SCS estimations in the present study depend on the empirical formulae based on long-term experiments in the four cropping regions. This division of the cropping regions may mask some spatial heterogeneity of SCS properties across China. However, this method is a most suitable analysis according to current data availability. Furthermore, the soil pool has a finite capacity to store organic C (Six et al., 2002) and other organic inputs can increase soil $C$ storage. These factors can increase uncertainties of SCS estimation in our study.

\subsection{Net mitigation potential}

Our results showed that implementation of the Recommendation might have a potential to significantly mitigate GHG emission by reducing $\mathrm{N}$ fertilization. In this study, the NMP of the FR scenario $(23.9 \pm$

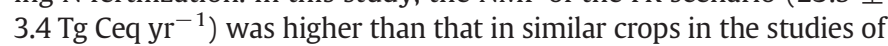
Chai et al. (2013) and Huang and Tang (2010), both of which estimated NMP by comparing with the $\mathrm{N}$ fertilization level in the late 1990s. In the

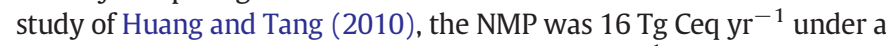
$50 \%$ improvement of $\mathrm{N}$ use efficiency (6.6 $\mathrm{Tg} \mathrm{N} \mathrm{yr}^{-1}$ reduction); while

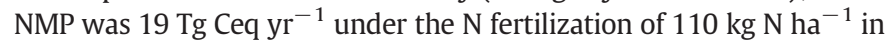
each cropping season in Chinese cropland (Chai et al., 2013). The higher NMP in our study is mainly due to the almost $19 \%$ increase of N fertilization over 10 years across all Chinese cropland (NBS, 2012). The NMP of this study can offset $1.1 \pm 0.16 \%$ of China's $\mathrm{CO}_{2}$ emissions from fuel combustion in 2011 (IEA, 2013). Moreover, reducing $\mathrm{N}$ fertilization can decrease other adverse global effects, for example atmospheric $\mathrm{N}$ deposition (Liu et al., 2013) and soil acidification (Guo et al., 2010) due to excessive $\mathrm{N}$ fertilization. Therefore, the implementation of the 
Recommendation could be an eco-friendly $\mathrm{N}$ fertilization management in China.

In this study, some factors might change during reducing the amount of $\mathrm{N}$ fertilizer (as in the Recommendation), for example, soil carbon sequestrations and $\mathrm{N}_{2} \mathrm{O}$ emission factors. In addition, there are other practices of $\mathrm{N}$ fertilization that affect GHG emission and mitigation. These practices included choice of fertilizer type, fertilization timing and placement (Millar et al., 2010; van Kessel et al., 2013). All these can introduce uncertainties in the estimation of NMP of the FR scenario in the present study. The effects of these practices on GHG dynamics require further field experiments concerning fertilization. Based on these experiments, direct measurements of changes of soil $\mathrm{C}$ fractions and GHG emissions will improve preciseness and spatial heterogeneity of model datasets.

\section{Conclusion}

Our results indicate that $\mathrm{N}$ fertilization level was $19.1 \pm 1.2 \mathrm{Mt} \mathrm{N}$ for the cropland of corn, wheat and rice throughout China in 2011. This amount could decrease by $7.1 \pm 1.3 \mathrm{Mt} \mathrm{N} \mathrm{yr}^{-1}$ in the FR scenario. This decrease might mitigate $37 \%$ of the $\mathrm{CO}_{2}$ emissions from production and transport of $\mathrm{N}$ fertilizer, and about $37 \%$ of $\mathrm{N}_{2} \mathrm{O}$ emission from soil due to $\mathrm{N}$ fertilization. The NMP of the FR scenario could be $23.9 \pm$ $3.4 \mathrm{Tg}$ Ceq $\mathrm{yr}^{-1}$ and might offset $1.1 \pm 0.16 \%$ of China's $\mathrm{CO}_{2}$ emissions from fossil fuel combustion in 2011. The overall results demonstrate that implementation of the Recommendation could be a sustainable and cost-effective $\mathrm{N}$ management system in China.

\section{Acknowledgments}

This study was supported by the National Natural Science Foundation of China under Grant 71003092, the Strategic Priority Program of Chinese Academy of Sciences under Grants XDA05050602 and XDA05060102, and Youth Innovation Promotion Association CAS. We would like to acknowledge Chunyan Zheng, Yi Wang and Yufei Li for assisting in this national-scale investigation. We thank the students of China Agriculture University for taking part in this national-scale investigation.

\section{Appendix A. Supplementary data}

Supplementary data to this article can be found online at http://dx. doi.org/10.1016/j.agsy.2016.03.012.

\section{References}

[IEA]International Energy Agency, 2013. $\mathrm{CO}_{2}$ emissions from fuel combustion-highlights (2013 edition). Available from http://www.iea.org/publications/freepublications/ publication/CO2EmissionsFromFuelCombustionHighlights2013.pdf (Accessed Febrary 10, 2015).

[IPCC] Intergovernmental Panel on Climate Change, 2000. Good Practice Guidance and Uncertainty Management in National Greenhouse Gas Inventories. IPCC/IGES, Japan.

[IPCC]Intergovernmental Panel on Climate Change, 2006. In: H.S., Eggleston, L., Buendia, K., Miwa, T., Ngara, K., Tanabe (Eds.), Guidelines for National Greenhouse Gas Inventories, Prepared by the National Greenhouse Gas Inventories Programme. Published: IGES, Japan.

[MOA] Ministry of Agriculture of the People's Republic China, 2013n. Recommendation for soil nutrient analysis-based fertilizer application for corn, wheat and rice (in Chinese). Available from http://www.moa.gov.cn/govpublic/ZZYGLS/201307/t20130729 3541508.htm (Accessed Febrary 10, 2015).

[NBS] National Bureau of Statistics of China, 2012. China Statistical Yearbook. electronic ed. China Statistics Press, Beijing.

Basche, A.D., Miguez, F.E., Kaspar, T.C., Castellano, M.J., 2014. Do cover crops increase or decrease nitrous oxide emissions? A meta-analysis. J. Soil Water Conserv. 69, $471-482$.

Brown, K.H., Bach, E.M., Drijber, R.A., Hofmockel, K.S., Jeske, E.S., Sawyer, J.E., Castellano M.J., 2014. A long-term nitrogen fertilizer gradient has little effect on soil organic matter in a high-intensity maize production system. Glob. Chang. Biol. 20, 1339-1350.

Chai, R., Niu, Y., Huang, L., Liu, L., Wang, H., Wu, L., Zhang, Y., 2013. Mitigation potential of greenhouse gases under different scenarios of optimal synthetic nitrogen application rate for grain crops in China. Nutr. Cycl. Agroecosyst. 96, 15-28.
Chen, C., Pan, J., Lam, S., 2014. A review of precision fertilization research. Environ. Earth Sci. 71, 4073-4080

Chen, S., Lu, F., Wang, X., 2015. Estimation of greenhouse emission factors of China's nitrogen, phosphate and potash fertilizers. Acta Ecol. Sin. 35, 1-19 (in Chinese)

Cui, Z., Zhang, F., Chen, X., Li, F., Tong, Y., 2011. Using in-season nitrogen management and wheat cultivars to improve nitrogen use efficiency. Soil Sci. Soc. Am. J. 75, 976-983.

Du, Z., Wang, W., Zeng, W., Zeng, H., 2014. Nitrogen deposition enhances carbon sequestration by plantations in Northern China. PLoS One 9, e87975.

Gao, X., 2008. Progress and development for fertilizing by prescription filled according to soil test result in China. Chin. J. Agric. Resour. Reg. Plan. 1, 005 (in Chinese).

Guo, J., Liu, X., Zhang, Y., Shen, J., Han, W., Zhang, W., Christie, P., Goulding, K., Vitousek, P., Zhang, F., 2010. Significant acidification in major Chinese croplands. Science 327. $1008-1010$

Hawkesford, M.j., 2014. Reducing the reliance on nitrogen fertilizer for wheat production. J. Cereal Sci. 59, 276-283.

Huang, Y., Tang, Y., 2010. An estimate of greenhouse gas $\left(\mathrm{N}_{2} \mathrm{O}\right.$ and $\left.\mathrm{CO}_{2}\right)$ mitigation potential under various scenarios of nitrogen use efficiency in Chinese croplands. Glob. Chang. Biol. 16, 2958-2970.

Jia, X., Huang, J., Xiang, C., Hou, L., Zhang, F., Chen, X., Cui, Z., Bergmann, H., 2013. Farmer's adoption of improved nitrogen management strategies in maize production in China: an experimental knowledge training. J. Integr. Agric. 12, 364-373.

Ju, X., Christie, P., 2011. Calculation of theoretical nitrogen rate for simple nitrogen recommendations in intensive cropping systems: a case study on the North China Plain. Field Crop Res. 124, 450-458.

Ju, X.T., Xing, G.X., Chen, X.P., Zhang, S.L., Zhang, L.J., Liu, X.J., Cui, Z.L., Yin, B., Christie, P., Zhu, Z.L., Zhang, F.S., 2009. Reducing environmental risk by improving N management in intensive Chinese agricultural systems. Proc. Natl. Acad. Sci. U. S. A. 106, 3041-3046.

Kahrl, F., Li, Y., Su, Y., Tennigkeit, T., Wilkes, A., Xu, J., 2010. Greenhouse gas emissions from nitrogen fertilizer use in China. Environ. Sci. Pol. 13, 688-694.

Lal, R., 2004. Carbon emission from farm operations. Environ. Int. 30, 981-990.

Lal, R., 2007. Carbon management in agricultural soils. Mitig. Adapt. Strateg. Glob. Chang. $12,303-322$.

Lebender, U., Senbayram, M., Lammel, J., Kuhlmann, H., 2014. Impact of mineral N fertilizer application rates on $\mathrm{N}_{2} \mathrm{O}$ emissions from arable soils under winter wheat. Nutr. Cycl. Agroecosyst. 100, 111-120.

Linquist, B.A., Adviento-Borbe, M.A., Pittelkow, C.M., van Kessel, C., van Groenigen, K.J., 2012. Fertilizer management practices and greenhouse gas emissions from rice systems: a quantitative review and analysis. Field Crop Res. 135, 10-21.

Liu, X., Zhang, Y., Han, W., Tang, A., Shen, J., Cui, Z., Vitousek, P., Erisman, J.W., Goulding, K., Christie, P., Fangmeier, A., Zhang, F., 2013. Enhanced nitrogen deposition over China. Nature 494, 459-462.

Lu, C. Tian, H., 2013. Net greenhouse gas balance in response to nitrogen enrichment: perspectives from a coupled biogeochemical model. Glob. Chang. Biol. 19, 571-588.

Lu, F., Wang, X.K., Han, B., Ouyang, Z.Y., Duan, X.N., Zheng, H., 2008. Assessment on the availability of nitrogen fertilization in improving carbon sequestration potential of China's cropland soil. Chin. J. Appl. Ecol. 19 (in Chinese).

Lu, F., Wang, X., Han, B., Ouyang, Z., Duan, X., Zheng, H., Miao, H., 2009. Soil carbon sequestrations by nitrogen fertilizer application, straw return and no-tillage in China's cropland. Glob. Chang. Biol. 15, 281-305.

Lu, C., Tian, H., Liu, M., Ren, W., Xu, X., Chen, G., Zhang, C., 2011a. Effect of nitrogen deposition on China's terrestrial carbon uptake in the context of multifactor environmental changes. Ecol. Appl. 22, 53-75.

Lu, M., Zhou, X., Luo, Y., Yang, Y., Fang, C., Chen, J., Li, B., 2011b. Minor stimulation of soil carbon storage by nitrogen addition: a meta-analysis. Agric. Ecosyst. Environ. 140, 234-244.

Ma, W., Li, J., Ma, L., Wang, F., Sisák, I., Cushman, G., Zhang, F., 2008. Nitrogen flow and use efficiency in production and utilization of wheat, rice, and maize in China. Agric. Syst. 99, 53-63.

Maillard, É., Angers, D.A., 2014. Animal manure application and soil organic carbon stocks: a meta-analysis. Glob. Chang. Biol. 20, 666-679.

Millar, N., Robertson, G.P., Grace, P., Gehl, R., Hoben, J., 2010. Nitrogen fertilizer management for nitrous oxide $\left(\mathrm{N}_{2} \mathrm{O}\right)$ mitigation in intensive corn (maize) production: an emissions reduction protocol for US Midwest agriculture. Mitig. Adapt. Strateg. Glob. Chang. 15, 185-204.

Peng, S., Buresh, R.J., Huang, J., Zhong, X., Zou, Y., Yang, J., Wang, G., Liu, Y., Hu, R., Tang, Q., Cui, K., Zhang, F., Dobermann, A., 2010. Improving nitrogen fertilization in rice by sitespecific N management: a review. Agron. Sustain. Dev. 30, 649-656.

Schlesinger, W.H., 2009. On the fate of anthropogenic nitrogen. P. Natl. Acad. Sci. USA. 106, 203-208.

Six, J., Conant, R.T., Paul, E.A., Paustian, K., 2002. Stabilization mechanisms of soil organic matter: implications for C-saturation of soils. Plant Soil 241, 155-176.

Sun, B., Zhao, H., Yizhong, L., Lu, F., Wang, X., 2015. The effects of nitrogen fertilizer application on methane and nitrous oxide emission/uptake in Chinese croplands. J. Integr. Agr. http://dx.doi.org/10.1016/S2095-3119(15)61063-2.

Tian, H., Xu, X., Lu, C., Liu, M., Ren, W., Chen, G., Melillo, J., Liu, J., 2011. Net exchanges of $\mathrm{CO}_{2}, \mathrm{CH}_{4}$, and $\mathrm{N}_{2} \mathrm{O}$ between China's terrestrial ecosystems and the atmosphere and their contributions to global climate warming. J. Geophys. Res. 116, G02011.

Townend, J., 2002. Practical Statistics for Environmental and Biological Scientists. Sons, John Wiley \&.

van Kessel, C., Venterea, R., Six, J., Adviento-Borbe, M.A., Linquist, B., van Groenigen, K.J., 2013. Climate, duration, and $\mathrm{N}$ placement determine $\mathrm{N}_{2} \mathrm{O}$ emissions in reduced tillage systems: a meta-analysis. Glob. Chang. Biol. 19, 33-44.

Venterea, R.T., Bijesh, M., Dolan, M.S., 2011. Fertilizer source and tillage effects on yieldscaled nitrous oxide emissions in a corn cropping system. J. Environ. Qual. 40, 1521-1531. 
Wang, X.K., Li, C.S., 2000. $\mathrm{N}_{2} \mathrm{O}$ emission from agricultural soil in China. Acta Sci. Circumst. 20, 483-488 (in Chinese)

West, T.O., Marland, G., 2002. A synthesis of carbon sequestration, carbon emissions, and net carbon flux in agriculture: comparing tillage practices in the United States. Agric. Ecosyst. Environ. 91, 217-232.

Yao, Z., Zheng, X., Dong, H., Wang, R., Mei, B., Zhu, J., 2012. A 3-year record of $\mathrm{N}_{2} \mathrm{O}$ and $\mathrm{CH}_{4}$ emissions from a sandy loam paddy during rice seasons as affected by different nitrogen application rates. Agric. Ecosyst. Environ. 152, 1-9.

Zhang, F., Wang, J., Zhang, W., Cui, Z., Ma, W., Chen, X., Jiang, R., 2008. Nutrient use efficiencies of major cereal crops in China and measures for improvement. Acta Pedol. Sin. 45, 915-924 (in Chinese).
Zhang, W.F., Dou, Z.X., He, P., Ju, X.T., Powlson, D., Chadwick, D., Norse, D., Lu, Y.L., Zhang, Y., Wu, L., Chen, X.P., Cassman, K.G., Zhang, F.S., 2013. New technologies reduce greenhouse gas emissions from nitrogenous fertilizer in China. Proc. Natl. Acad. Sci. U. S. A. $110,8375-8380$

Zheng, X., Fu, C., Xu, X., Yan, X., Huang, Y., Han, S., Hu, F., Chen, G., 2002. The Asian nitrogen cycle case study. Ambio 31, 79-87. 